\title{
EDITORIAL
}

\section{CENÁRIO DA PRODUÇÃO CIENTÍFICA NA ENFERMAGEM EM FOCO}

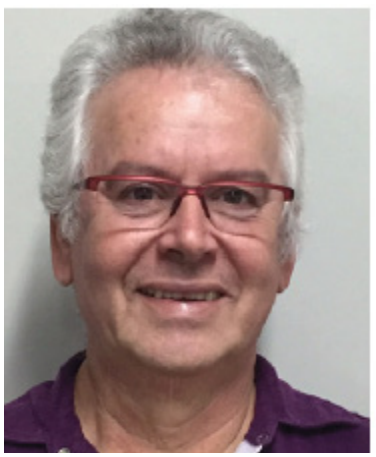

Joel Rolim Mancia

Editor-chefe da revista Enfermagem em Foco. Unisinos - POA/RS.

A cada final de ano costumamos fazer um balanço/relato atualizado sobre a revista Enfermagem em Foco. Sempre com o pensamento em entregar boas notícias. No ano de 2018, tivemos um número significativo de novas submissões à avaliação da revista, foram avaliados 494 manuscritos, dos quais 160 foram aceitos, 60 já publicados e permanecem 100 no processo de avaliação. Destacando-se o não cumprimento das normas como o motivo mais frequente de devolução. Assim, temos um índice de rejeição em torno de $70 \%$ ainda na primeira avaliação. Está abaixo dos índices internacionais que se aproximam dos $90 \%$.

Como as normas de publicação são dinâmicas e os pesquisadores também seguem tendências em pesquisa, ainda publicamos muitos textos de revisão. Alguns periódicos, entre eles a Journal Advanced of Nursing publicam preferentemente revisões sistemáticas e relatórios de pesquisa, deixando de fora os textos mais reflexivos, discursivos, de opinião. Esse tipo de decisão, ainda que revestido de subjetividade, se deve ao possivel benefício do fator de impacto.

A qualidade dos manuscritos que publicamos melhora de ano a ano, a revista está mais atrativa para os pesquisadores mais renomados, aqueles que são citados, e promovem a melhoras das métricas da revista, notadamente o Google Scholar. Esses pesquisadores são vitais para os periódicos que buscam uma melhor posição no ranking das métricas melhor posicionadas nas avaliações dos financiadores de pesquisa e de avaliações de carreira profissional.
Embora aceitemos originais em espanhol e inglês, na expectativa de um melhor diálogo com uma audiência internacional, ainda estamos carentes da produção dos demais países da América Latina.

Em vista disto o Conselho Editorial deliberou pela divulgação dos textos integrais publicados em três idiomas. $\mathrm{O}$ que certamente ampliará o universo de leitores do periódico e as possibilidades de citação em âmbito internacional.

A atualização mais importante a ser relatada é a renovação do Conselho Editorial com a introdução de novos editores associados, quais sejam: Dra. Isabel Cristina Kowal Olm Cunha, da Universidade Federal de São Paulo(UNIFESP); Dr. Carlos Leonardo Figueiredo Cunha, da Universidade Federal do Pará (UFPA) e Dr. Rosemiro Guimarães Ximenes Neto Universidade Estadual Vale do Acaraú (UVA).

A enfermagem não é regular no Twitter em nosso país, mas ele é um fórum vibrante, vivo para manter informação atualizada e conectando-nos uns com os outros. Adotaremos essa ferramenta à medida que viabilizemos nosso Office. Meu endereço pessoal é @manciajr, pode ser usado a vontade.

Que tenhamos um excelente 2019! 